\title{
Antimicrobial activity in leaf, seed extract and seed oil of J atropha curcas L. plant
}

\author{
Sanj ay M ohan Gupta*, M ohommad A rif and Zakwan A hmed \\ Molecular Biology and Genetic Engineering Laboratory, Defence Institute of Bio-Energy Research, Haldwani-263139, \\ INDIA \\ *Corresponding author. E-mail: smg555@rediffmail.com
}

\begin{abstract}
The study on antibacterial and antifungal efficacy of leaf and seed extract and seed oil of J atropha curcas reveals that the inhibition zones ranged from 7 to $22 \mathrm{~mm}$ for antibacterial and from 10 to $20 \mathrm{~mm}$ for antifungal activity. Among all extracts tested, seed extract showed significant activity while leaf extract showed intermediate activity against gram-positive bacteria. In case of gram-negative bacteria, seed extract and seed oil has shown some moderate activity whereas, no activity was observed in leaf extract. In case of fungal cultures, among all test extracts only seed extract showed significant activity against Mucor and Tilletia fungus, while in case of R hizopus no activity was observed against all test extracts. These results indicated the possibility of using Jatropha extract and seed oil for medicinal uses and natural food preservation.
\end{abstract}

Keywords: Antimicrobial activity, J atropha curcas L., Crude leaf and seed extract, Seed oil, Agar disc diffusion assay

\section{INTRODUCTION}

In recent years there has been an increasing interest in the use of natural bioactive compounds, and some questions concerning the safety of synthetic compounds have encouraged more detailed studies of plant resources. Infectious diseases caused by bacteria and fungus accounts for high proportion of health problems in the developing countries including India. Microorganisms have developed resistance to many antibiotics due to indiscriminate use of commercial antimicrobial drugs encouraged scientists to search for new antimicrobial substances from various sources including medicinal plants (Karaman et al., 2003).

Jatropha curcas (Euphorbiaceae family) is a multipurpose plant that has a long history of cultivation in tropical America, Africa, and Asia with many attributes, mainly as potential source of bio-fuel because its seed kernels contain a high amount of oil (58-60\%) (Fairless, 2007). Besides oils, Jatropha seeds also contain high protein, anti-nutritional factors including trypsin inhibitor, lectin, saponin, phytic acid and toxic compounds called phorbol esters (Martinez-Herrera et al., 2006). The natural compounds of Jatropha exhibits bioactive activities for fever, mouth infections, jaundice, guinea worm sores and joint heumatism (Aiyelaagbe et al., 2007; Bhushan et al., 2008). Furthermore, extracts from various parts of Jatropha curcas, such as seeds, seed oil, stem barks, roots and leaves have shown fungicidal (Nwosu and Okafor, 1995; Saetae and Worapot, 2010) and bactericidal properties (Igbinosa et al., 2009).

ISSN : 0974-9411 All Rights Reserved @ Applied and Natural Science Foundation. www.ansfoundation.org
The present study was aimed to evaluate the antibacterial and antifungal efficacy of crude leaf and seed extract and seed oil of J atropha curcas on two gram-positive bacteria (Bacillus subtilis and Bacillus thuringiensis), four gram-negative bacteria (Pseudomonas fluorescens, Escherichia coli, Agrobacterium tumefaciens and Acinetobactor junii) and three fungal cultures (Rhizopus oryzae, Mucor indicus and Tilletia indica) causing infections/diseases.

\section{MATERIALS AND METHODS}

Bacterial cultures namely, B. subtil is (NCTC 10073), B. thuringiensis (MTCC 4714), P. fluorescens (NCTC 10038), E. coli (NCTC 9002), A. tumefaciens (MTCC 609) and A. junii (MTCC 1686) and fungal cultures namely, R hizopus oryzae (MTCC 262), M. indicus (MTCC 3318) and T. indica were obtained from Department of Molecular Biology Genetic Engineering, G. B. Pant University of Agriculture \& Technology, Pantnagar.

J atropha curcas leaves were collected from DIBER, Haldwani, where the plant grows under natural conditions. The fresh leaves (5 gm) were ground in porcelain mortar and the leaf paste was squeezed through muslin cloth to give fresh crude leaf extract and 101 of the extract was applied on disc 1. The same extract was concentrated (four fold) in centrivap concentrator (Labconco, Biogentek, India) and 101 of this was applied on disc 2. The extract was also dried completely in centrivap concentrator and dissolved in 501 of Dimethyl Sulphoxide (DMSO) by keeping the tubes in the 
water bath at $37^{\circ} \mathrm{C}$ for one hour and cleared by centrifugation at $10,000 \times \mathrm{g}$ for $2 \mathrm{~min}$ and $10 \mathrm{l}$ of the supernatant was applied on disc 3. Clarified crude leaf extract (centrifuged at $10000 \mathrm{x} \mathrm{g}$ for $10 \mathrm{~min}$ ) was concentrated four fold in centrivap concentrator and 10 1 of this was applied on disc 4 . The remaining aliquot of this supernatant was dried completely in centrivap concentrator and dissolved in 501 of DMSO as described earlier and $10 \mathrm{il} \mathrm{of} \mathrm{this} \mathrm{was} \mathrm{applied} \mathrm{on} \mathrm{disc} 5$. Mature seeds (5 g) of J atropha curcas were also ground in porcelain mortar using $5 \mathrm{ml}$ DMSO as described earlier to give fresh crude seed extract and 101 of the extract were applied on disc 6 . The crude seed extract was concentrated (four fold) in centrivap concentrator and 10 il of this was applied on disc 7. Dried seeds were powdered and successively extracted in a Soxhlet extractor for $8 \mathrm{~h}$ at $65^{\circ} \mathrm{C}$ with petroleum ether for the extraction of Jatropha seed oil according to the standard procedure of Soxhlet (1879) and 101 of fresh seed oil was applied on disc 8. Standard antibacterial (Kanamycin, $1000 \mathrm{~g} / \mathrm{ml}$ ) and antifungal (Clotrimazole, $100 \mathrm{~g} / \mathrm{ml}$ ) drugs were applied separately on disc 9 as positive control. The DMSO solvent was also applied on disc 10 as negative control.

In vitro antimicrobial studies were carried out on different bacterial and fungal cultures against test extracts (leaf, seed extract and seed oil) by agar disc diffusion assay method (Gupta et al., 2009). A $100 \quad 1$ aliquots of bacterial (about $10^{6}$ cells $/ \mathrm{ml}$ ) and fungal cultures (about $10^{8} \mathrm{cfu} /$ $\mathrm{ml}$ ) were evenly spreaded on to LA (Luria agar, Himedia) and PDA (Potato dextrose agar, Himedia) plates $(90 \mathrm{~mm}$ diameter) using a sterile glass rod spreader, respectively. The plates were left at room temperature for $15 \mathrm{~min}$. to allow the agar surface to dry. The sterile disc $(6 \mathrm{~mm}$, Himedia) containing the standard drug and test compounds were placed on the inoculated plates. The LA and PDA plates were incubated at $37^{\circ} \mathrm{C}$ and $30^{\circ} \mathrm{C}$ for 24 to $48 \mathrm{~h}$, respectively. Experiment was performed under strict aseptic conditions. Cleared zones were scored as antimicrobial activity of standard drug and test compounds against different tested microorganisms. The antibacterial and antifungal activity was evaluated by measuring the diameter of the inhibition zone. The experiments were performed in triplicate and the data were calculated as mean \pm SD.

\section{RESULTS AND DISCUSSION}

In order to investigate the antibacterial and antifungal activity of different extracts (leaf, seed extracts and seed oil) of Jatropha plant, disc diffusion assay was performed. The presence of zones of clearance speculates that the extract present in the disc has antimicrobial activity. In our experiment among 8 extracts (Fresh crude leaf extract, concentrated crude leaf extract, dried crude leaf extract dissolved in DMSO, concentrated supernatant of fresh crude leaf extract, dried supernatant of fresh crude leaf extract dissolved in DMSO, fresh crude seed extract, concentrated crude seed extract and seed oil) tested, 2 extracts (Crude seed extract and concentrated crude seed extract) of Jatropha showed significant and 3 extracts (Dried crude leaf extract dissolved in DMSO, concentrated supernatant of crude leaf extract and dried supernatant

Table 1. Antimicrobial activity in leaf, seed extract and seed oil of $J$ atropha curcas.

\begin{tabular}{|c|c|c|c|c|c|c|c|c|c|c|}
\hline \multirow[t]{2}{*}{$\begin{array}{l}\text { Disc } \\
\text { No. }\end{array}$} & \multirow[t]{2}{*}{ Compound } & \multicolumn{6}{|c|}{$\begin{array}{c}\text { A ntibacterial activity } \\
\text { (Diameter of inhibition zone in } \mathrm{mm} \text { ) }\end{array}$} & \multicolumn{3}{|c|}{$\begin{array}{c}\text { Antifungal activity } \\
\text { (Diameter of inhibition } \\
\text { zone in } \mathrm{mm} \text { ) }\end{array}$} \\
\hline & & BT & BS & AGRO & $\mathrm{ESH}$ & PSE & $\mathrm{ACl}$ & $\mathrm{RHI}$ & MUC & TILL \\
\hline 1 & Fresh crude leaf extract & - & - & - & - & - & - & - & - & - \\
\hline 2 & Concentrated crude leaf extract & - & - & - & - & - & - & - & - & - \\
\hline 3 & $\begin{array}{l}\text { Dried crude leaf extract } \\
\text { dissolved in DMSO }\end{array}$ & 7 & 7 & - & - & - & - & - & - & - \\
\hline 4 & $\begin{array}{l}\text { Concentrated supernatant of } \\
\text { fresh crude leaf extract }\end{array}$ & 7 & 7 & - & - & - & - & - & - & - \\
\hline 5 & $\begin{array}{l}\text { Dried supernatant of fresh } \\
\text { crude leaf extract dissolved in } \\
\text { DMSO }\end{array}$ & 8 & 8 & - & - & - & - & - & - & - \\
\hline 6 & Fresh crude seed extract & 13 & 10 & 7 & 7 & 7 & 7 & - & 10 & - \\
\hline 7 & Concentrated crude seed extract & 14 & 11 & 8 & 7 & 7 & 8 & - & 11 & 13 \\
\hline 8 & Seed oil & - & 7 & - & 7 & - & 7 & - & - & - \\
\hline 9 & Standard drug & 18 & 22 & 21 & 20 & 15 & 17 & 20 & 19 & 18 \\
\hline 10 & DMSO & - & - & - & - & - & - & - & - & - \\
\hline
\end{tabular}

$\mathrm{BT}=$ Bacillus thuringiensis, $\mathrm{BS}=$ Bacillus subtilis, $\mathrm{AGRO}=$ Agrobacterium tumefaciens, $\mathrm{ESH}=\mathrm{E}$. coli, $\mathrm{PSE}=$ Pseudomonas fluorescens, ACI = Acinetobactor junii, RHI = Rhizopus oryzae, MUC = M ucor indicus and TILL = Tilletia indica. 
of crude leaf extract dissolved in DMSO) showed intermediate activity against both gram-positive bacteria. In case of all gram-negative bacteria, Fresh crude seed extract, concentrated crude seed extract and seed oil has shown some moderate mar much activity whereas, no activity was observed in any leaf extracts (Table 1). Higher resistance of gram-negative bacteria to external agents has been earlier reported and it is attributed to the presence of lipopolysaccharides in their outer membrane, which make them inherently resistance to antibiotic, detergent and hydrophilic dyes (Nikaido and Varra, 1985) Similar trend for inhibition of bacterial growth has been observed in earlier studies with other plant extract (Negi and Jayaprakasha, 2003). The reason for higher sensitivity of the gram-positive bacteria than negative bacteria could be ascribed to the differences between their cell wall compositions. The gram-positive bacteria contain an outer peptidoglycan layer, which is an ineffective permeability barrier (Scherrer and Gerhardt, 1971). In case of fungal cultures, among all test extracts only crude seed extract (Disc 6) and concentrated crude seed extract (Disc 7) showed significant activity against M ucor and Tilletia fungus, while in case of Rhizopus no activity was observed against all test extracts. Concentrated crude seed extract (Disc 7) of Jatropha exhibited highest antifungal and antibacterial activity as compared to other extract tested. The inhibition zones ranged from 7 to 22 $\mathrm{mm}$ for antibacterial and from 10 to 20 for antifungal activity, respectively (Table 1). According to Bauer et al. (1996) the microbicidal activity is classified into resistant if the zone of inhibition in millimeter is less then 7 . If it is $7-9 \mathrm{~mm}$ intermediate, if the inhibition is 10 or more it is sensitive. Hence in this study leaf, seed extract and seed oil of Jatropha gives sensitive microbicidal activity. J atropha curcas contains higher steroids, terpenoids (mainly, phorbol ester), flavonoids and alkaloids (mainly, jatrophine) compounds in the leaf and seed in comparison to other species of Jatropha (Krishnan and Paramathma, 2009). It is speculated that higher antibacterial and antifungal activities of different extract of Jatropha may be due to presence of these phenolic compounds. The Jatropha leaf extract was effective in controlling the fungal pathogens Sclerotium sp. and Colletotrichum musae which, causes azolla and anthracnose diseases, respectively (Thangavelu et al., 2004). Furthermore, the latex of Jatropha contains an alkaloid known as 'Jatrophine' which is used as a hemostatic and wound dressing (Esimone et al., 2009) and is said to be efficacious in treating scabies, wasp and bee stings, treat bleeding gums, toothache, anti-inflammation, eczema and ringworm (de-Feo, 1989; Van-den et al., 1995). In addition, antibacterial activity of extracts of Jatropha seed oil, root and stem bark was also reported by many workers (Solsoloy and Solsoloy, 1997; Aiyelaagbe, 2007; Igbinosa et al., 2009). Recently, the ethanolic extract of J . curcas seed cake showed antifungal activities against important fungal phytopathogens (Saetae and Worapot, 2010). The microbicidal activity of Jatropha extracts is probably due to their ability to form complex with extra cellular and soluble proteins and bacterial cell walls by nonspecific forces such as hydrogen bonding and hydrophobic effects, as well as by covalent bond formation. Thus, their mode of antimicrobial actions may be related to their ability to inactive microbial adhesins, enzymes, cell envelope transport proteins, etc. There is also evidence for direct inactivation of microorganisms (Scalbert, 1991). Therefore, the present observations suggest that J atropha curcas is a potential source of bioactive antimicrobial agents.

\section{ACKNOWLEDGEMENTS}

We thank the DRDO, Min. of Defence, Govt. of India for financial support and scientific staff of DIBER is acknowledged for providing help during the preparation of this manuscript. Dr. Anil Kumar, Prof and Head, Dept. of MBGE, GBPUA\&T, Pantnagar is also acknowledged for providing bacterial and fungal strains used in the present study.

\section{REFERENCES}

Aiyelaagbe, O.O., Adeniyi, B.A., Fatunsin, O.F. and Arimah, B.D. (2007). In-vitro antimicrobial activity and photochemical analysis of J atropha curcas roots. Intern. J . Pharmacol., 3(1): 106-110.

Bauer, A.W., Kirby, W.M., Sherris, J.C. and Turck, M. (1996). Antibiotic susceptibility testing by standardized single disc method. Am. J. Clin Pathol., 44: 493-496.

Bhushan, B., Prakash, I. and Abhay, F. (2008). Evaluation of antimicrobial activity of medicinal plant $J$ atropha podagrica (Hook). Roumanian Biotechnological Letters, 13 (5): 38733877.

De-Feo, V. (1989). Uso di planti ad azione antiinflammatoria nell'Alto Ucayall, Peru Oriental. Fitoter apia, 62: 481-494.

Esimone, C.O., Nworu, C.S. and Jackson, C.L. (2009). Cutaneous wound healing activity of a herbal ointment containing the leaf extract of J atropha curcas L. (Euphorbiaceae). Int. J of Appl. Res. Nat. Prod., 1(4): 1-4.

Fairless, D. (2007). Bio-fuel: The little shrub that could-may be. Nature, 449: 652-655.

Gupta, S., Kumar, N. and Gupta, S.M. (2009). Antibacterial and antifungal activity in extract and oil of piper betle landrace bangla mahoba. J. Adv. Zoo., 30(1): 16-20.

Igbinosa, O.O., Igbinosa, E.O. and Aiyegoro, O.A. (2009). Antimicrobial activity and phytochemical screening of stem bark extracts from J atropha curcas (Linn). African J ournal of Pharmacy and P harmacology, 3(2): 58-62.

Karaman, I., Sahin, P., Gulluce, M., Oguten, H., Songul, M. and Adiguzed, A. (2003). Antimicrobial activity of aqueous and methanol extracts of J uniperus oxycedrus L. J E thanopharmacol ., 2837: 1-5.

Krishnan, P.R. and Paramathma, M. (2009). Potentials and J atropha species wealth of India. Current Science, 97(7): 
1000-1004.

Martinez-Herrera, J., Siddhuraju, P., Francis, G., Davilá-Ortíz, G. and Becker, K. (2006). Chemical composition, toxic/ antimetabolic constituents and effects of different treatments on their levels in four provenances of J atropha curcas L. from Mexico. Food C hem., 96: 80-89.

Negi, P.S. and Jayaprakasha, G.K. (2003). Antioxidant and antibacterial activities of Punica granatum peel extracts. J ournal of F ood Science, 68: 1473-1477.

Nikaido, H. and Vaara, M. (1985). Molecular basis of bacterial outer membrane permeability. Microbiological Reviews, 49: $1-32$

Nwosu, M.O. and Okafor, J.I. (1995). Preliminary studies of the antifungal activities of some medicinal plants against Basidiobolus and some other pathogenic fungi. M ycoses, 38: 191-195.

Saetae, D. and Worapot, S. (2010). Antifungal Activities of Ethanolic Extract from Jatropha curcas Seed Cake. J . Microbiol. Biotechnol., 20 (2): 319-324.

Scalbert, A. (1991). Antimicrobial properties of tannin.
Photochemistry, 30: 3875-3883.

Scherrer, R. and Gerhardt, P. (1971). Molecular sieving by the Bacillus megatrium cell wall and protoplast. J ournal of Bacteriology, 107: 718-735.

Solsoloy, A.D. and Solsoloy, T.S. (1997). Pesticidal efficacy of formulated $J$. curcas oil on pests of selected field crops. In: Biofuels and Industrial Products from Jatropha curcas (Gübitz GM, Mittelbach M \& Trabi M, eds.), DBV Graz., pp. 216-226.

Soxhlet, F. (1879). Die genichtsanalytische bestimmung des miichfettes. Dingler Poly Technisches J ournal, 232: 461.

Thangavelu, R., Sundararaju, P. and Sathiamoorthy, S. (2004). Management of anthracnose disease of banana caused by Colletotrichum musae using plant extracts. J. Hort. Sci. Biotechnol., 79: 664-668.

Van-den Berg, A.J.J., Horsten, S.F.A., Ketteness-van den Bosch, J.J., Kroes, B.H., Beukelman, C.J., Leeflang, B.R., Labadie, R.P. and Curcacycline, A. (1995). A novel cyclic octapeptide isolated from the latex of J atropha curcas L. FE BS L ett. , 358: 215-218. 